\title{
Identification of transport parameters of chlorides in different soils on the basis of column studies
}

\author{
Damian Pietrzak, Jarosław Kania, Ewa Kmiecik*, Katarzyna Wątor \\ AGH University of Science and Technology, Mickiewicza 30 Av., 30-059 Kraków, Poland \\ *corresponding author, e-mail: ewa.kmiecik@agh.edu.pl
}

\begin{abstract}
Knowledge of transport patterns of chemicals in groundwater is essential for environmental assessment of their potential impact. In the present study, the mobility of a chloride tracer injected into three different soils was investigated, using column experiments. The column tests were performed under steady-state conditions to determine parameters of chloride migration through soils. Based on breakthrough curves, pore-water velocity, dispersion coefficient and dispersivity constant were calculated for each soil sample using CXTFIT/STANMOD software. Pore-water velocity was in the range of $0.31 \mathrm{~cm} / \mathrm{min}$ for fine sand, to $0.35 \mathrm{~cm} / \mathrm{min}$ for silty sand and to $0.40 \mathrm{~cm} / \mathrm{min}$ for vari-grained sand. The highest values of dispersion coefficient and dispersivity constant were observed for silty sand $\left(0.55 \mathrm{~cm}^{2} / \mathrm{min}\right.$ and 1.55 $\mathrm{cm}$, respectively), while the lowest value was found for fine sand $\left(0.059 \mathrm{~cm}^{2} / \mathrm{min}\right.$ and $0.19 \mathrm{~cm}$, respectively). Column experiments for chlorides (conservative tracer) are a preliminary stage for further research which will be undertaken to investigate migration parameters of selected neonicotinoids (reactive tracers) through different soils.
\end{abstract}

Key words: pore-water velocity, dispersion coefficient, dispersivity constant, CXTFIT, STANMOD

\section{Introduction}

Groundwater is an essential environmental constituent and must be protected for the benefit of the present and future generations. Nowadays, an increasing number of substances generated by waste from residential, commercial, industrial and agricultural activities are detected in the soil-water environment (Patil \& Chore, 2015). The fate and transport of dissolved chemical substances in groundwater generates considerable interest in view of concerns for the quality of the subsurface environment. These chemicals can enter the groundwater system via a wide range of mechanisms. Once introduced into an aquifer, they will be transported by flowing groundwater and may degrade water quality at nearby wells and streams. Many factors can affect the transport of contaminants in the aqui- fer, including media properties and a large number of physical, chemical and microbial processes, the most important of which are dispersion, dilution, volatilization, sorption and biodegradation (Kania \& Witczak, 2011; Witczak et al., 2013).

For improving management and protection of groundwater resources, it is important to recognise how the various pollutants migrate in the aquifer and to identify the possibility of their removal or dilution. There are various methods that can be used to forecast the migration of contaminants (Fox et al., 2010; Rolle et al., 2012; Swami et al., 2013; Patil \& Chore, 2014). Apart from defining boundary conditions, analytical and computer simulation methods require knowledge of flow and transport parameters (Kania \& Witczak, 2011). Based on literature research (e.g., Okońska et al., 2009; Marciniak et al., 2013; Swami et al., 2013; Sharma et al., 2014; Patil 
\& Chore, 2015) an appropriate method for column experiments was applied.

Here we present the results of column experiments which were used to find parameters of chloride (conservative) tracer transport in three different soil types. Parameters of tracer transport were calculated using a CXTFIT model included in STANMOD software on the basis of laboratory data (breakthrough curves of chloride concentrations vs time).

\section{Material and methods}

\subsection{Material tested}

The tests were carried out on samples of different soils - silty (soil 1), fine (soil 2) and vari-grained (soil 3) sands, which were prepared in the laboratory. Three types of permeable soil were selected to investigate the influence of granulation on the values of transport parameters. Identification of particle-size distribution was conducted using the sieve analysis according to the procedure presented in the PN-EN ISO 17892-4:2017-01 standard. The contents of particular fractions are illustrated in particle-size distribution curves (Fig. 1). Textural names of the soils tested were determined on the basis of the classification according to the PN-EN ISO 14688 standard.

\subsection{Column experiments}

A soil sample was placed in a steel cylinder with a length of $15.8 \mathrm{~cm}$ and a diameter of $6.4 \mathrm{~cm}$, under saturated conditions. The column was carefully wetpacked with soils progressively from the bottom to the top in order to avoid air bubble formation within. The soil columns were saturated with distillate water from the bottom. Above and below the material a paper filter and steel wool were placed to avoid clogging of the inlet and outlet ports. Water/tracer was provided to the column by a peristaltic pump with a flow rate of $3.46-3.54 \mathrm{~mL} / \mathrm{min}$ (Table 1$)$. The experiment was conducted at room temperature (c. $22^{\circ} \mathrm{C}$ ). The same procedure was applied for all three soils and for each sample one experiment was conducted. A description of experiment conditions can be found in Table 1, while a schematic experimental set-up used in the column experiments and experiment procedures are illustrated in Figure 2.

A solution of $500 \mathrm{mg} / \mathrm{L}$ of chloride (conservative tracer undergoing advection and dispersion processes) was prepared from an appropriate $\mathrm{NaCl}$ sample weight dissolved in deionized water. The tests were carried out using short-term injection with a volume of $300 \mathrm{~mL}$ of chloride tracer. The outlet solution was collected every $50 \mathrm{~mL}$ (minimum volume required for laboratory analyses). Chloride concentrations in the elutes were analysed directly using the titration method. The experiment ran for 221, 198 and 208 min for soils 1, 2 and 3, respectively.

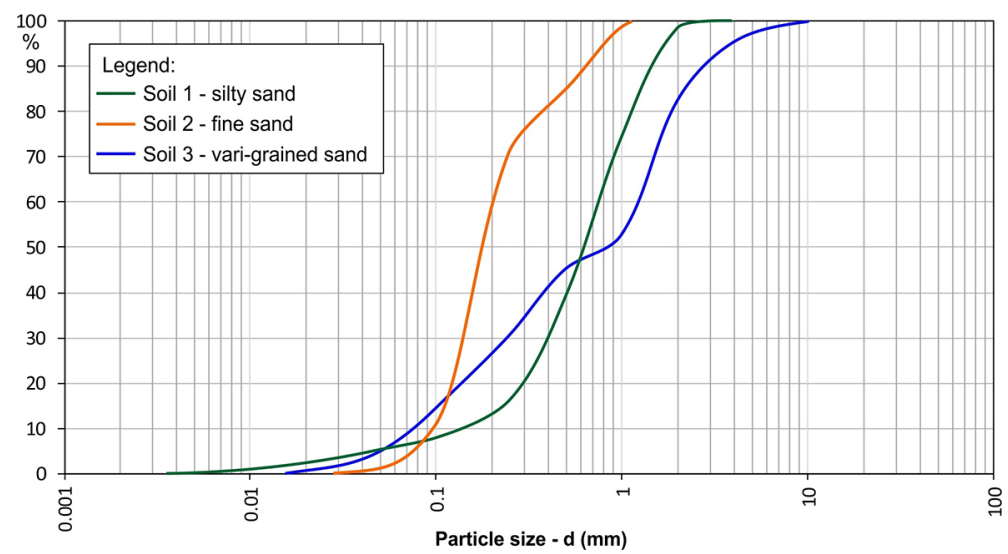

Fig. 1. Particle size distribution of the soils tested

Table 1. Description of experiment conditions.

\begin{tabular}{lcccc}
\hline \multirow{2}{*}{ Soil sample } & Volume of water collected & Time of experiment & Mean flow rate & Water flow velocity \\
\cline { 2 - 5 } Soil 1 - silty sand & $\mathrm{mL}$ & $\min$ & $\mathrm{mL} / \mathrm{min}$ & $\mathrm{cm} / \mathrm{min}$ \\
Soil 2 - fine sand & 750 & 221 & 3.47 & 0.108 \\
Soil 3 - multi-grained sand & 700 & 198 & 3.54 & 0.110 \\
\hline
\end{tabular}




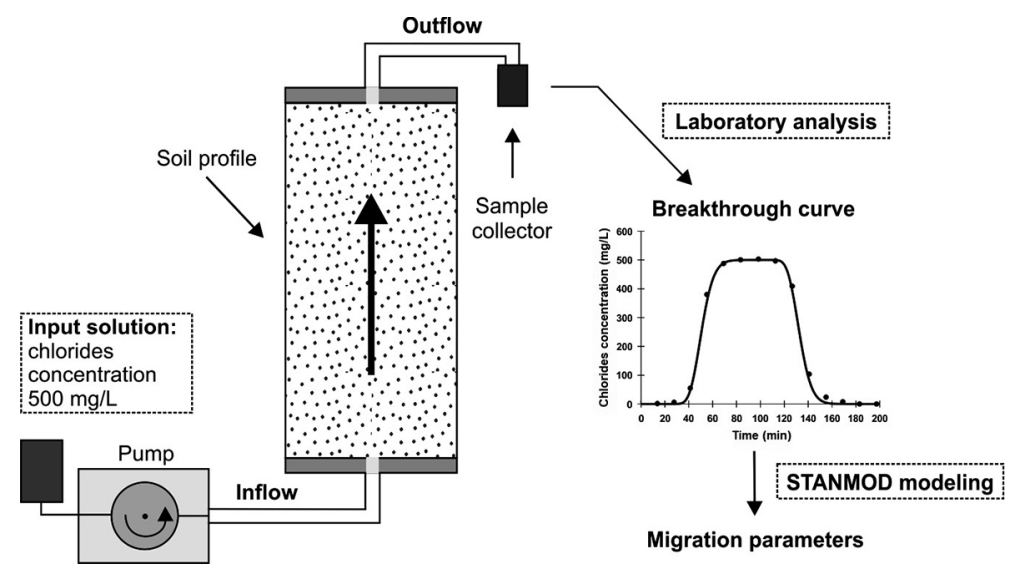

Fig. 2. Experimental set-up and experiment procedures for testing chloride transport parameters

Column experiments for chlorides rank amongst research methods for investigating the migration of selected neonicotinoids in groundwater (Kmiecik et al., 2017; Pietrzak et al., 2019a, b). The use of chlorides as a conservative tracer made it possible to check the correctness of initial assumptions (based on literature data) and the correct technical preparation of the experiment. On this basis, further column studies will be undertaken for neonicotinoids (reactive tracer) using the previously described soils first.

\subsection{Parameter estimations}

To assess the parameters of contaminant transport, a number of analytical and model tests are commonly used (Rolle et al., 2012; Sharma et al., 2014; Fernández-Bayo et al., 2015; Kret et al., 2015; Patil \& Chore, 2015; Okońska et al., 2019a, b). Here, CXTFIT/STANMOD software was used for simulating the transport of chloride tracer in soils.

The CXTFIT program (Toride et al., 1995) may be used to estimate parameters in several analytical models for solute transport during steady one-dimensional flow by fitting the parameters to laboratory or field data observed, obtained from solute displacement experiments. The program may be employed to solve direct or forward problems to determine concentrations as a function of time and/or position (Parker \& Genuchten, 1992; Toride et al., 1995). The inverse problem is solved by minimising an objective function, which consists of the sum of the squared differences between observed and fitted concentrations. To minimise the objective function a nonlinear least-squares inversion method, according to Marquardt (1963), is used. The STANMOD software package (Simunek et al., 1999) includes a modified and updated version of the CXTFIT code of Toride et al. (1995) for estimating solute transport parameters using a nonlinear least-squares parameter optimisation method.

Among the basic parameters that characterise the process of substance migration in groundwater, the following initially estimated parameters (with minimum and maximum values) were introduced to the numerical model: pore-water velocity $(v)$, dispersion coefficient $(D)$ and retardation factor $(R)$. Pore-water velocity was calculated taking into account the effective porosity, determined on the basis of laboratory tests.

CXTFIT/STANMOD software was used to determine breakthrough curves (BTCs) and transport parameters based on deterministic equilibrium convection-dispersion equation (CDE) solving the inverse problem. BTCs were a result of a pulse injection of $500 \mathrm{mg} / \mathrm{L}$ chloride solution to initially solute-free saturated soils - one injection for each soil. The time of injection for soils 1, 2 and 3 was 90, 82 and $86 \mathrm{~min}$, respectively. Data for the inverse problem were entered on the basis of experimental data and it was position $(15.8 \mathrm{~cm})$, time and concentration of chlorides in samples collected (14-15 samples). On the basis of all input data, the program estimated pore-water velocity $(v)$ and dispersion coefficient (D), by fitting one of the analytical solutions to specified experimental data, solving the inverse problem.

\section{Results and discussion}

In the column experiment, three BTCs were registered. BTCs are plotted in Figure 2 as chloride concentrations (mg/L) vs time (min). In all three cases, the CXTFIT/STANMOD transport model matched the experimental data well, with a coefficient of determination $\mathrm{R}^{2}$ equal to 0.99 for soil 2 and 3 and 0.98 for soil 1 . 
Table 2. Parameters of chloride transport obtained using the CXTFIT-STANMOD package

\begin{tabular}{lcccc}
\hline \multicolumn{1}{c}{ Parameter } & Unit & Soil 1 & Soil 2 & Soil 3 \\
\hline Pore-water velocity $(v)$ & $\mathrm{cm} / \mathrm{min}$ & 0.353 & 0.309 & 0.399 \\
Dispersion coefficient $(D)$ & $\mathrm{cm}^{2} / \mathrm{min}$ & 0.547 & 0.059 & 0.092 \\
Dispersivity constant & $\mathrm{cm}$ & 1.55 & 0.19 & 0.23 \\
Retardation factor $(R)$ & - & 1 & 1 & 1 \\
\hline
\end{tabular}

Values of pore-water velocity $(v)$, dispersion coefficient $(D)$ and dispersivity constant, calculated in the program, are presented in Table 2. Pore-water velocity for soils 1, 2 and 3 were $0.353,0.309$ and $0.399 \mathrm{~cm} / \mathrm{min}$, respectively. The highest value of dispersion coefficient and dispersivity constant was observed for soil $1\left(0.55 \mathrm{~cm}^{2} / \mathrm{min}\right.$ and $1.55 \mathrm{~cm}$, respectively), while the lowest value was for soil 2 $\left(0.059 \mathrm{~cm}^{2} / \mathrm{min}\right.$ and $0.19 \mathrm{~cm}$, respectively).

Based on breakthrough curves obtained, it was determined that the granulation of soils has an influence on the value of transport parameters and therefore on the shape of breakthrough curves, which can be observed in Figure 3. The BTCs for fine and vari-grained sands have greater width than for silty sand. In the case of silty sand, there is a sharp peak followed by a decrease in chloride concentration, while for the other two soils a longer transit time of the highest concentrations (4-5 samples) is observed. Soil granulation also influences the time of total chloride migration through the column - the greater the content of the thicker fraction, the faster the transition time. Similar relationships have previously been observed by, for instance, Marciniak et al. (2013) and Sharma et al. (2014).
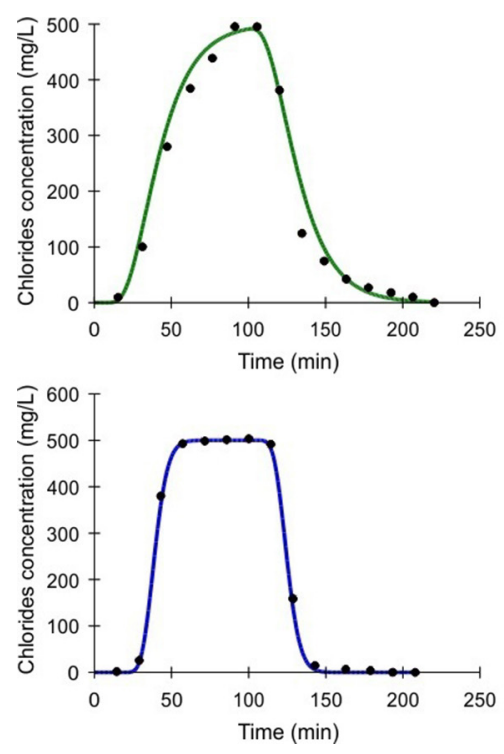

\section{Conclusions}

Column experiments are an efficient method to provide input data for numerical modelling of both non-reactive and reactive tracers transport and fate in the soil-water system for the purpose of surface and groundwater protection. In the present study, an attempt has been made to investigate the behaviour of conservative tracer transport through different soils using column experiments. On the basis of these experiments, result migration parameters of chlorides were obtained. Experiments were conducted for three different soils - silty, fine and vari-grained sands. The column experiment is a relatively simple and cheap method that allows to set easily various input values for further modelling using specific computer software. In this particular case, laboratory data were used to simulate the transport of a chloride tracer in soils with the CXTFIT/STANMOD software. By solving the inverse problem the program fits a variety of mathematical solutions of theoretical transport models to experimental results and estimated solute transport parameters - pore-water velocity and dispersion coefficient. As a result, three BTCs were registered and for all three soils the transport model fitted the experimental data well, with $\mathrm{R}^{2}$ equal to 0.99 . The calculated pore-water velocity for soils 1,2 and 3 were $0.353,0.309$ and $0.399 \mathrm{~cm} / \mathrm{min}$, respectively. Dispersion coefficient and dispersivity constant were also obtained. The highest value was observed for soil $1\left(0.547 \mathrm{~cm}^{2} / \mathrm{min}\right.$ and $1.55 \mathrm{~cm}$, respectively), while soil 2 had the lowest value $\left(0.059 \mathrm{~cm}^{2} / \mathrm{min}\right.$ and $0.19 \mathrm{~cm}$, respectively).
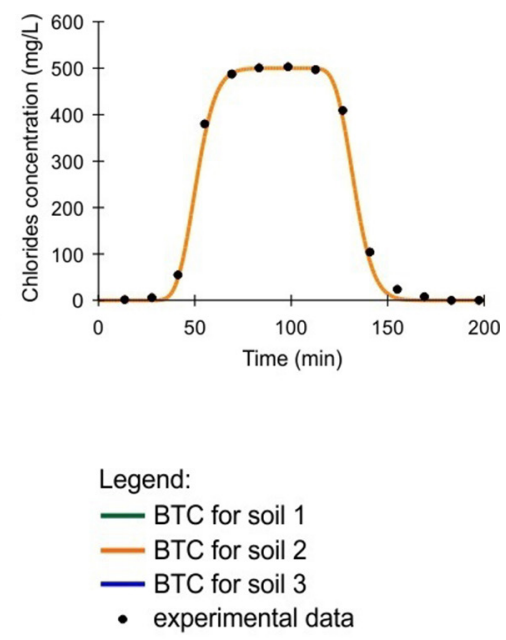

Fig. 3. Experimental data and fitted breakthrough curves for chlorides 


\section{References}

Fernández-Bayo, J.D., Nogales, R. \& Romero, E., 2015. Winery vermicomposts to control the leaching of diuron, imidacloprid and their metabolites: Role of dissolved organic carbon content. Journal of Environmental Science and Health - Part B Pesticides, Food Contaminants, and Agricultural Wastes 50, 190-200.

Fox, P.J., Lee, J. \& Lenhart, J.J., 2010. Coupled consolidation and contaminant transport in compressible porous media. International Journal of Geomechanics 11, 113-123.

Kania, J. \& Witczak, S., 2011. Modele migracji zanieczyszczeń [Contaminants transport models]. [In:] S. Dąbrowski, J. Kapuściński, K. Nowicki, J. Przybyłek \& A. Szczepański (Eds): Metodyka modelowania matematycznego w badaniach $i$ obliczeniach hydrogeologicznych - poradnik metodyczny [Mathematical modelling in hydrogeological studies and calculations: a methodological handbook]. Bogucki Wydawnictwo Naukowe, Poznań, 313-332.

Kmiecik, E., Wątor, K., Pietrzak, D., Kania, J. \& Witczak, S., 2017. Pesticides in waters in Poland - problems, assignment and challenges. IWA $10^{\text {th }}$ Micropol \& Ecohazard Conference, Vienna, Austria.

Kret, E., Kiecak, A., Malina, G., Nijenhuis, I. \& Postawa, A., 2015. Identification of TCE and PCE sorption and biodegradation parameters in a sandy aquifer for fate and transport modelling: batch and column studies. Environmental Science and Pollution Research 22, 98779888.

Marciniak, M., Okońska, M., Kaczmarek, M. \& Kazimierska-Drobny, K., 2013. Analiza parametryczna krzywej przejścia znacznika przez kolumnę filtracyjną [The sensitivity test for a breakthrough curve recorded during tracer migration in a filtration column]. Biuletyn Państwowego Instytutu Geologicznego 456, 385-390.

Marquardt, D.W., 1963. An algorithm for least-squares estimation of nonlinear parameters. Journal of the Society for Industrial and Applied Mathematics 11, 431-441.

Okońska, M., Marciniak, M. \& Kaczmarek, M., 2019a. The pulse descriptors in sensitivity studies of no-sorption and single-sorption column transport models. Journal of Porous Media 22, 563-582.

Okońska, M., Kaczmarek, M. \& Marciniak, M., 2019b. The pulse descriptors in sensitivity studies of hybrid sorption column transport models. Journal of Porous Media 22, 647-662.

Okońska, M., Marciniak, M., Kaczmarek, M. \& Kazimierska-Drobny, K., 2009. Identification of filtration and migration parameters in the MATLAB calculation environment using numerical simulation of breakthrough curve and optimization methods. Water Resources Management V 125, 471-482.

Parker, J.C. \& Genuchten, M.T., 1992. Determining transport parameters from laboratory and field tracer ex- periments. Virginia Agricultural Experiment Station 84, 1-97.

Patil, S.B. \& Chore, H.S., 2014. Contaminant transport through porous media: An overview of experimental and numerical studies. Advances in Environmental Research 3, 45-69.

Patil, S.B. \& Chore, H.S., 2015. Transport of chloride through saturated soil column: An experimental study. Advances in Environmental Research 4, 105-117.

Pietrzak, D., Kania, J., Malina, G., Kmiecik, E. \& Wątor, K., 2019a. Pesticides from the EU first and second Watch Lists in the water environment. Clean - Soil, Air, Water 47, 1-13.

Pietrzak, D., Wątor, K., Pękała, D., Wójcik, J., Chochorek, A., Kmiecik, E. \& Kania, J., 2019b. LC-MS/MS method validation for determination of selected neonicotinoids in groundwater for the purpose of a column experiment. Journal of Environmental Science and Health, Part B: Pesticides, Food Contaminants, and Agricultural Wastes 54, 424-431.

Rolle, M., Hochstetler, D., Chiogna, G., Kitanidis, P.K. \& Grathwohl, P., 2012. Experimental investigation and pore-scale modeling interpretation of compound-specific transverse dispersion in porous media. Transport in Porous Media 93, 347-362.

Sharma, P.K., Sawant, V.A., Shukla, S.K. \& Khan, Z., 2014. Experimental and numerical simulation of contaminant transport through layered soil. International Journal of Geotechnical Engineering 8, 345-351.

Simunek, J., van Genuchten, M.T., Sejna, M., Toride, N. \& Leij, F.J., 1999. The STANMOD computer software for evaluating solute transport in porous media using analytical solutions of convection-dispersion equation. Version 1.0 and 2.0. IGWMC-TPS 71, International Ground Water Modeling Center, Colorado School Of Mines, Golden, $32 \mathrm{pp}$.

Swami, D., Sharma, P.K. \& Ojha, C.S.P., 2013. Experimental investigation of solute transport in stratified porous media. ISH Journal of Hydraulic Engineering 19, 145-153.

Toride, N., Leij, F.J. \& van Genuchten, M.Th., 1995. The CXTFIT code for estimating transport parameters from laboratory and field tracer experiments. Version 2.0. Research Report No. 137, U.S. Salinity Laboratory, Riverside, $121 \mathrm{pp}$.

Witczak, S., Kania, J. \& Kmiecik, E., 2013. Katalog wybranych fizycznych i chemicznych wskaźników zanieczyszczeń wód podziemnych i metod ich oznaczania [Guidebook on selected physical and chemical indicators of groundwater contamination and methods of their determination]. Biblioteka Monitoringu Środowiska, Warszawa, 717 pp.

Manuscript received: 28 March 2019 Revision accepted: 22 August 2019 